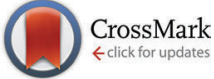

Cite this: J. Mater. Chem. B, 2016, 4, 5101

Received 4th June 2016

Accepted 4th July 2016

DOI: 10.1039/c6tb01392a

www.rsc.org/MaterialsB

\section{A novel method for the synthesis of 1,2-benzisoxazoline-3-one and its application to hypochlorite recognition $\dagger$}

\author{
Yutao Yang, $\neq^{\mathrm{ab}}$ Fangjun Huo, $\neq^{\mathrm{b}}$ Caixia Yin, ${ }^{\mathrm{a}}$ Ming $\mathrm{Xu},{ }^{\mathrm{c}}$ Ying $\mathrm{Hu},{ }^{\mathrm{d}}$ Jianbin Chao, ${ }^{\mathrm{b}}$ \\ Yongbin Zhang, ${ }^{b}$ Timothy E. Glass ${ }^{* c}$ and Juyoung Yoon*d
}

The reaction of salicylhydroxamic acid with hypochlorite produces 1,2-benzisoxazoline-3-one, a heterocycle that contains a fluorophore. As a result, this reaction was used as the basis for a new, selective and sensitive fluorescence system for the recognition of hypochlorite. The effectiveness of the method was demonstrated by its use to detect hypochlorite in a disinfectant solution as well as to image hypochlorite in cells.

In modern-day organic chemistry, a growing trend exists to develop green and sustainable synthetic processes. ${ }^{1,2}$ The preparation of heterocyclic compounds has remained an important issue in synthetic chemistry because these substances play important roles in coordination chemistry, biochemistry, and pharmaceutical and materials science. ${ }^{3}$ Many biologically active natural products are heterocycles that are used in the agrochemical, pharmaceutical and flavorant industries. ${ }^{4,5}$ For example, 1,2-benzisoxazole derivatives have been widely utilized as anti-cancer, anti-microbial and anti-thrombotic agents. ${ }^{6}$ As a result, the observation that 1,2-benzisoxazoline-3-ones can be prepared from hydroxamic acids, using either thionyl chloride at low temperature, or $1,1^{\prime}$-carbonyldiimidazole (CDI) at high temperature, is relevant. ${ }^{7}$ The design and discovery of new methods to synthesize heterocyclic compounds, like 1,2-benzisoxazoline-3-ones, remain important.

Reactive oxygen species (ROS) are involved in a number of biological functions. ${ }^{8}$ Among ROS, the hypochlorite ion $\left(\mathrm{ClO}^{-}\right)$ has gained importance because of the biological roles it plays. ${ }^{9}$ The hypochlorite ion is produced in living systems mainly by

\footnotetext{
${ }^{a}$ Institute of Molecular Science, Key Laboratory of Materials for Energy Conversion and Storage of Shanxi Province, Shanxi University, Taiyuan 030-006, P. R. China. E-mail: yincx@sxu.edu.cn

${ }^{b}$ Research Institute of Applied Chemistry, Shanxi University, Taiyuan, 030006, China

${ }^{c}$ Department of Chemistry, University of Missouri 601 South College Avenue, Columbia, Missouri 65211, USA. E-mail: glasst@missouri.edu

${ }^{d}$ Department of Chemistry and Nano Science, Ewha Womans University, Seoul, 120-750, Korea.E-mail: jyoon@ewha.ac.kr

$\dagger$ Electronic supplementary information (ESI) available. See DOI: 10.1039/c6tb01392a

\# Contributed equally to this work.
}

myeloperoxidase (MPO) catalyzed peroxidation of chloride ions. ${ }^{10}$ However, because of its high and nonselective reactivity, abnormal production of hypochlorite can lead to various diseases including cardiovascular ailments, ${ }^{11}$ arthritis, ${ }^{12}$ neuronal degeneration ${ }^{13}$ and cancer. ${ }^{14}$ As a consequence, methods for sensitive and selective detection of the hypochlorite ion are highly significant. To date, a variety of fluorescent probes for $\mathrm{ClO}^{-}$sensing, which are designed based on HOCl induced oxidation reactions, have been described. ${ }^{15}$ However, fluorescent probes that display a fluorescence enhancement (turn-on) response and that function in $100 \%$ aqueous media are scarce. In addition, tedious synthetic procedures for these probes can have serious disadvantages. In the current study, we report a simple, rapid and economical method to sense $\mathrm{ClO}^{-}$.

The method uncovered to prepare 1,2-benzisoxazoline-3-one (2), shown in Scheme 1, is both simple and efficient. Specifically, treatment of a methanol solution of salicylhydroxamic acid (1) at ambient temperature with excess sodium hypochlorite leads to rapid (30 s) formation of 2 . This heterocycle is isolated in $82 \%$ yield following implementation of a simple extraction procedure. Compound 2 was confirmed by ${ }^{1} \mathrm{H}-\mathrm{NMR},{ }^{13} \mathrm{C}-\mathrm{NMR}$ and ESI-MS.

Because 1,2-benzisoxazoline-3-one is fluorescent and the oxidation reaction producing it is both rapid and efficient, we envisaged that the process would serve as the basis for a new method for HOCl detection and imaging the physiological generation of this ROS. In Fig. 1 emission spectra are displayed which show the fluorescence changes that occur when $\mathrm{ClO}^{-}$ (1.0 equiv.) and other ROS and RNS (10 equiv., $\mathrm{H}_{2} \mathrm{O}_{2},{ }^{1} \mathrm{O}_{2},{ }^{\bullet} \mathrm{O}^{2-}$, $\mathrm{ROO}^{\bullet}, \mathrm{NO}^{\bullet}$ and $\left.{ }^{\circ} \mathrm{OH}\right)$ are added to aqueous HEPES $(10 \mathrm{mM}$, $\mathrm{pH}$ 7.4) solutions of $\mathbf{1}$. The spectra demonstrate that only $\mathrm{ClO}^{-}$

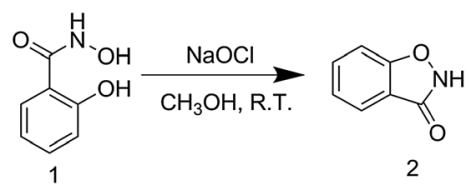

Scheme 1 Synthesis of 1,2-benzisoxazoline-3-one (2) from salicylhydroxamic acid (1) using hypochlorite. 

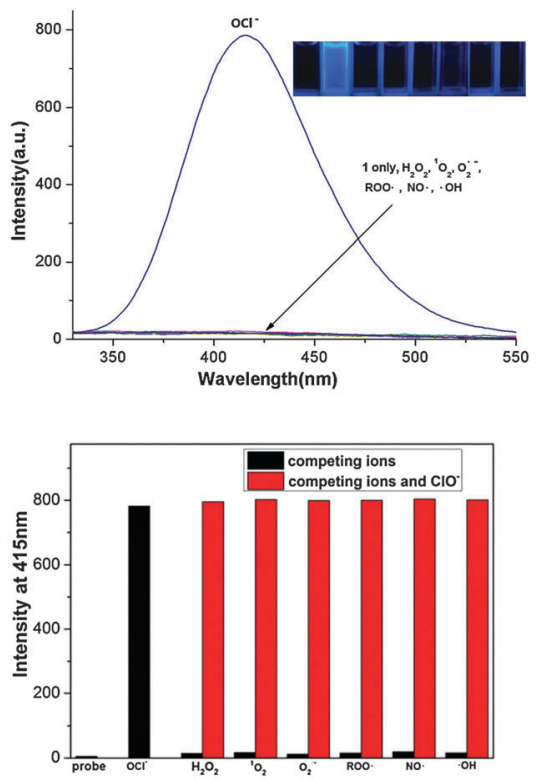

Fig. 1 Top: Fluorescence spectra of mixtures of $1(10 \mu \mathrm{M})$ and other ROS and RNS $(100 \mu \mathrm{M})$ including $\mathrm{ClO}^{-}, \mathrm{H}_{2} \mathrm{O}_{2},{ }^{1} \mathrm{O}_{2}, \mathrm{O}_{2}{ }^{\bullet-}, \mathrm{ROO} \cdot \mathrm{NO} \cdot \cdot \cdot \mathrm{OH}$ in HEPES $\left(10 \mathrm{mM}, \mathrm{pH}\right.$ 7.4) $\left(\lambda_{\mathrm{ex}}=300 \mathrm{~nm}\right)$. In the inset are photographic images of mixtures of 1 containing $\mathrm{ClO}^{-}$(blue) and other anions (colorless) under illumination with a $365 \mathrm{~nm}$ UV lamp. Bottom: Fluorescence intensities $(415 \mathrm{~nm})$ of the probe $(2.5 \mu \mathrm{M})$ upon the addition of $2.5 \mu \mathrm{M} \mathrm{ClO}^{-}$in the presence of $25 \mu \mathrm{M}$ of the other analytes in HEPES (10 mM, pH 7.4) solutions. Black bar: probe + various analytes. Red bar: probe + various anions $+\mathrm{ClO}^{-}\left(\lambda_{\mathrm{ex}}=300 \mathrm{~nm}, \lambda_{\mathrm{em}}=415 \mathrm{~nm}\right)$.

causes production of 2 in association with a large increase in the intensity of the fluorescence band with a maximum at $415 \mathrm{~nm}$ (300 $\mathrm{nm}$ excitation). UV-Vis spectroscopic monitoring of the reaction between 1 and $\mathrm{ClO}^{-}$shows that an increase in absorption occurs at $265 \mathrm{~nm}$ as the reaction proceeds (Fig. S3, $\mathrm{ESI} \dagger$ ) and fluorescence titration data show that a $\mathrm{ClO}^{-}$concentration dependent fluorescence enhancement occurs at $415 \mathrm{~nm}$ (Fig. 2a).

Analysis of the fluorescence titration profile of the reaction of $1(2.5 \mu \mathrm{M})$ with $\mathrm{ClO}^{-}$demonstrates that the limit of detection of the system for $\mathrm{ClO}^{-}$is $49 \mathrm{nM}$ (Fig. 2b). As shown in Fig. S5 $(\mathrm{ESI} \dagger)$, probe 1 shows fluorescence enhancement at $\mathrm{pH}$ in the range of 6-12 upon the addition of $\mathrm{HOCl}$.

Time-dependent changes in the fluorescence spectra, brought about by the addition of 10 equiv. of $\mathrm{ClO}^{-}$to a solution of 1 , were monitored. The results (Fig. 3) show that reaction to form 2 is completed within $30 \mathrm{~s}$, indicating that the probe reacts rapidly with this ROS under the conditions employed. This fast response suggests that the process can be possibly employed directly for the quantitative detection of $\mathrm{ClO}^{-}$.

The ability of 1 to be used to visualize $\mathrm{ClO}^{-}$within living cells was also evaluated. For this purpose, laser confocal fluorescence imaging was carried using a Leica TCS SP5 laser scanning microscope, with an optical window in the blue channel (400-450 nm) as a signal output. As the images given in Fig. 4a show, HepG2 cells incubated with the $2.5 \mu \mathrm{M}$ probe for $30 \mathrm{~min}$ at $37^{\circ} \mathrm{C}$ do not fluoresce when selectively excited at
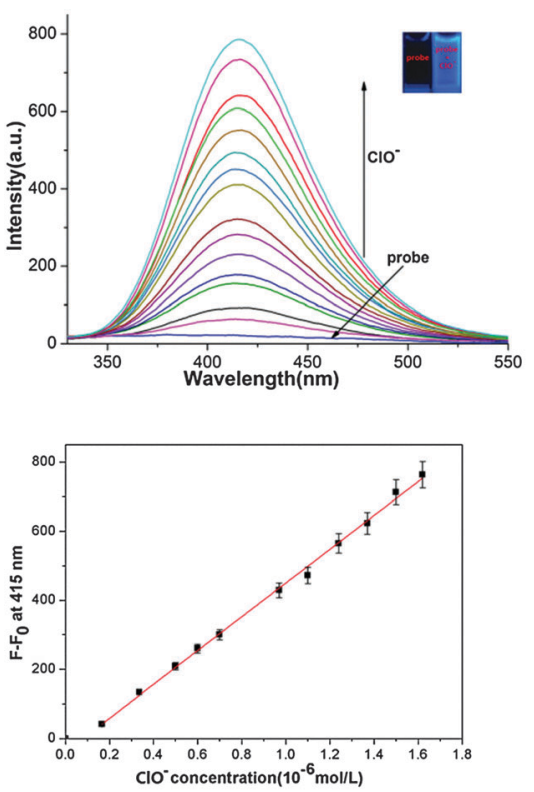

Fig. 2 Top: Fluorescence spectra of $1(2.5 \mu \mathrm{M})$ in the presence of various concentrations of $\mathrm{ClO}^{-}(0-1.8 \mu \mathrm{M})$ in HEPES $(10 \mathrm{mM}, \mathrm{pH}$ 7.4) $\left(\lambda_{\mathrm{ex}}=300 \mathrm{~nm}\right)$. Bottom: Plot of intensities of fluorescence at $415 \mathrm{~nm}$ as a function of the concentrations of $\mathrm{ClO}^{-}$.

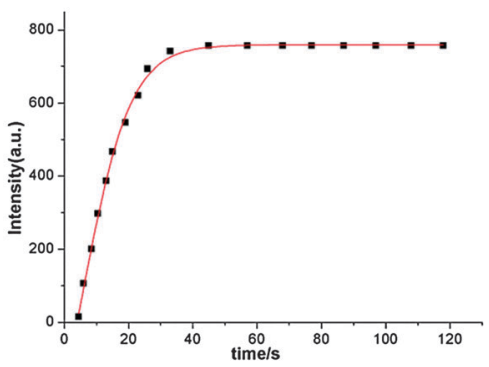

Fig. 3 Reaction time profile of probe 1 and $\mathrm{ClO}^{-}$.

$300 \mathrm{~nm}$. In contrast, HepG2 cells do display blue fluorescence after they are incubated with $2 \mu \mathrm{M}$ of $\mathbf{1}$ for $30 \mathrm{~min}$ at $37^{\circ} \mathrm{C}$ and then treated with $5 \mu \mathrm{M} \mathrm{ClO}^{-}$(Fig. 4b). The results of these
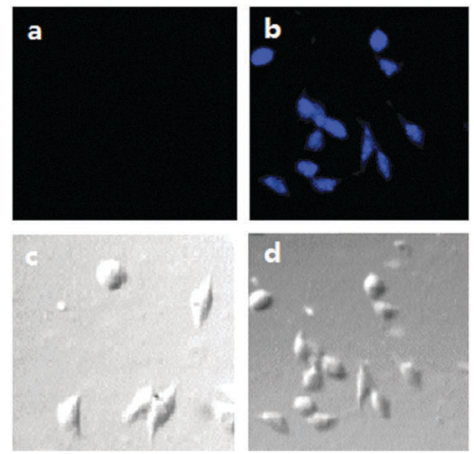

Fig. 4 Confocal fluorescence microscope (a) and bright field (c) images of HepG2 cells in the absence of 1 . Confocal fluorescence microscope (b) and bright field (d) images of HepG2 cells following incubation with $2.5 \mu \mathrm{M} 1$ for $10 \mathrm{~min}$ followed by addition of $5 \mu \mathrm{M} \mathrm{ClO}^{-}$. 
Table 1 Determination of $\mathrm{HOCl}$ concentration in a disinfectant

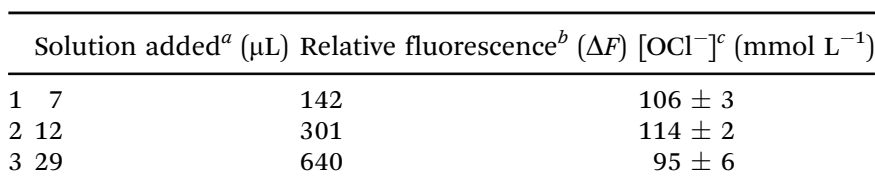

${ }^{a}$ Diluted 1000 fold. $^{b} 2.5 \mu \mathrm{M}$ probe in $10 \mathrm{mM}$ HEPES, pH 7.4. ${ }^{c}$ Hypochlorite concentration of sodium hypochlorite disinfectant $(n=5)$.

whole cell experiments demonstrate that the new probe is cell permeable and that it can be used to visualize $\mathrm{ClO}^{-}$within living cells.

To investigate the applicability of the new probe for monitoring $\mathrm{ClO}^{-}$in real samples, the levels of this ROS in a common disinfectant were examined (Table 1). Aliquots of a commercial bleach solution, without pretreatment, were added to a solution of $\mathbf{1}$ in buffer. By comparing the observed fluorescence intensities to those of a standard curve (Fig. S4, ESI $\dagger$ ), the concentration of $\mathrm{ClO}^{-}$in the bleach sample was determined to be $105 \pm 3 \mathrm{mM}$ (Table S1, ESI $\dagger$ ).

In summary, in this study we uncovered a simple, rapid and economical method for synthesis of the interesting heterocycle, 1,2-benzisoxazoline-3-one, using $\mathrm{ClO}^{-}$promoted oxidation of salicylhydroxamic acid at room temperature for $30 \mathrm{~s}$. Compared with traditional protocols used to prepare this substance, ${ }^{7}$ the new method is more environmentally benign. In addition, we demonstrated that this process can be used as a fluorescent probe for $\mathrm{ClO}^{-}$. The application of this method to the synthesis of other heterocyclic compounds and to the development of new fluorescent probes with longer wavelength emission characteristics is under current investigation.

The work was supported by the National Natural Science Foundation of China (No. 21472118), the Taiyuan Technology star special (No. 12024703), the Program for the Top Young and Middle-aged Innovative Talents of Higher Learning Institutions of Shanxi (2013802), the Talents Support Program of Shanxi Province (2014401), the Shanxi Province Outstanding Youth Fund (No. 2014021002) and the National Science Foundation (CHE-1507119). This research was also supported by a grant from the National Creative Research Initiative programs of the National Research Foundation of Korea (NRF) funded by the Korean government (MSIP) (No. 2012R1A3A2048814).

\section{Notes and references}

1 (a) L. G. Voskressensky, A. A. Festa and A. V. Varlamov, Tetrahedron, 2014, 70, 551-572; (b) L. F. Tietze, Chem. Rev., 1996, 96, 115; (c) F. F. Wei, Y. Lu, S. He, L. C. Zhao and X. S. Zeng, Anal. Methods, 2012, 4, 616.

2 V. Polshettiwar and R. S. Verma, Curr. Opin. Drug Discovery Dev., 2007, 10, 723.

3 G. C. Rodrigues, D. F. Feijó, M. T. Bozza, P. Pan, D. Vullo, S. Parkkila, C. T. Supuran, C. Capasso, A. P. Aguiar and A. B. Ver-melho, J. Med. Chem., 2014, 57, 298.

4 R. Properzi and E. Marcantoni, Chem. Soc. Rev., 2014, 43, 779.
5 I. Flament and C. Chevalier, Chem. Ind., 1988, 18, 592.

6 (a) M. Pinho and M. V. D. Teresa, Curr. Org. Chem., 2005, 9, 925; (b) M. Jain and C. H. Kwon, J. Med. Chem., 2003, 46, 5428.

7 W. Liu, F. Lau, K. Liu, H. B. Wood, G. Zhou, Y. Chen, Y. Li, T. E. Akiyama, G. Castriota, M. Einstein, C. Wang, M. E. McCann, T. W. Doebber, M. Wu, C. H. Chang, L. McNamara, B. McKeever, R. T. Mosley, J. P. Berger and P. T. Meinke, J. Med. Chem., 2011, 54, 8541.

8 (a) X. Chen, F. Wang, J. Y. Hyun, T. Wei, J. Qiang, X. Ren, I. Shin and J. Yoon, Chem. Soc. Rev., 2016, 45, 2976; (b) X. Chen, X. Tian, I. Shin and J. Yoon, Chem. Soc. Rev., 2011, 40, 4783; (c) X. H. Li, G. X. Zhang, H. M. Ma, D. Q. Zhang, J. Li and D. B. Zhu, J. Am. Chem. Soc., 2004, 126, 11543.

9 (a) X. H. Cheng, H. Z. Jia, T. Long, J. Feng, J. G. Qin and Z. Li, Chem. Commun., 2011, 47, 11978; (b) S. Khati, R. Musa and J. Vaya, Bioorg. Med. Chem., 2007, 15, 3661.

10 Y. K. Yang, H. J. Cho, J. Lee, I. Shin and J. Tae, Org. Lett., 2009, 11, 859.

11 S. Sugiyama, K. Kugiyama, M. Aikawa, S. Nakamura, H. Ogawa and P. Libby, Arterioscler., Thromb., Vasc. Biol., 2004, 24, 1309.

12 M. J. Steinbeck, L. J. Nesti, P. F. Sharkey and J. J. Parvizi, J. Orthop. Res., 2007, 25, 1128.

13 D. I. Pattison and M. J. Davies, Chem. Res. Toxicol., 2001, 14, 1453.

14 D. I. Pattison and M. J. Davies, Biochemistry, 2006, 45, 8152. 15 (a) Q. L. Xu, C. H. Heo, G. Kim, H. W. Lee, H. M. Kim and J. Yoon, Angew. Chem., Int. Ed., 2015, 54, 4890; (b) Q. L. Xu, S. Lee, K. M. Lee, W. J. Lee and J. Yoon, J. Am. Chem. Soc., 2013, 135, 9944; (c) L. Yuan, L. Wang, B. K. Agrawalla, S. J. Park, H. Zhu, B. Sivaraman, J. Peng, Q. H. Xu and Y. T. Chang, J. Am. Chem. Soc., 2015, 137, 5930; (d) L. Yuan, W. Y. Lin and H. Chen, Biomaterials, 2013, 34, 9566; (e) Q. A. Best, N. Sattenapally, D. J. Dyer, C. N. Scott and M. E. McCarroll, J. Am. Chem. Soc., 2013, 135, 13365; $(f)$ Y. Koide, Y. Urano, K. Hanaoka, T. Terai and T. Nagano, J. Am. Chem. Soc., 2011, 133, 5680; (g) Z. Lou, P. Li, Q. Pan and K. Han, Chem. Commun., 2013, 49, 2445; (h) J. J. Hu, N. K. Wong, Q. Gu, X. Bai, S. Ye and D. Yang, Org. Lett., 2014, 16, 3544; (i) H. Zhu, J. Fan, J. Wang, H. Mu and X. J. Peng, J. Am. Chem. Soc., 2014, 136, 12820; (j) X. Chen, K. A. Lee, E. M. Ha, K. M. Lee, Y. Y. Seo, H. K. Choi, H. N. Kim, M. J. Kim, C. S. Cho, S. Y. Lee, W. J. Lee and J. Yoon, Chem. Commun., 2011, 47, 4373; (k) W. Y. Lin, L. L. Long and B. B. Chen, Chem. - Eur. J., 2009, 15, 2305; (l) J. Zhou, L. H. Li, W. Shi, X. H. Gao, X. H. Li and H. M. Ma, Chem. Sci., 2015, 6, 4884; $(m)$ S. Kenmoku, Y. Urano and H. Kojima, J. Am. Chem. Soc., 2007, 129, 7313; (n) N. Zhao, Y. H. Wu, R. M. Wang, L. X. Shi and Z. N. Chen, Analyst, 2011, 136, 2277; (o) F. J. Huo, J. J. Zhang, Y. T. Yang, J. B. Chao, C. X. Yin, Y. B. Zhang and T. G. Chen, Sens. Actuators, B, 2012, 44, 166; ( $p$ ) J. Kim and Y. Kim, Analyst, 2014, 139, 2986; (q) J. L. Fan, H. Y. Mu, H. Zhu, J. Y. Wang and X. J. Peng, Analyst, 2015, 140, 4594; (r) W. Zhang, W. Liu, P. Li, J. Q. Kang, J. Y. Wang, H. Wang and 
B. Tang, Chem. Commun., 2015, 51, 10150; $(s)$ X. Chen, K. A. Lee, X. Ren, J. C. Ryu, G. Kim, J. H. Ryu, W. J. Lee and J. Yoon, Nat. Protoc., 2016, 11, 1219; (t) Q. Xu, C. H. Heo, J. A. Kim, H. S. Lee, Y. Hu, D. Kim, K. M. K. Swamy, G. Kim, S. J. Nam, H. M. Kim and J. Yoon, Anal. Chem., 2016, 88, 6615; (u) S. Goswami, K. Aich, S. Das, B. Pakhira, K. Ghoshal, C. K. Quah, M. Bhattacharyya, H. K. Fun and
S. Sarkar, Chem. - Asian J., 2015, 10, 694; (v) S. Goswami, S. Das, K. Aich, P. K. Nandi, K. Ghoshal, C. K. Quah, M. Bhattacharyya, H. K. Fun and H. A. Abdel-Aziz, RSC Adv., 2014, 4, 24881; (w) S. Goswami, A. K. Das, A. Manna, A. K. Maity, P. Saha, C. K. Quah, H. K. Fun and H. A. Abdel-Aziz, Anal. Chem., 2014, 86, 6315; (x) S. Goswami, A. Manna, S. Paul, C. K. Quah and H. Fun, Chem. Commun., 2013, 49, 11656. 